\title{
Organizational Environment and Work Satisfaction of the Employees of Hitachi Chemical Montemorelos Nuevo León México
}

\author{
Omar A. Flores Laguna, Sandy M. Velázquez Hernández, Karla S. Basurto Gutiérrez \\ University of Montemorelos, Mexico \\ Karla L. Haro-Zea \\ Meritorious Autonomous University of Puebla, Mexico
}

\begin{abstract}
This study seeks to answer one question: The quality level of organizational environment. Is it an indicator of the workplace satisfaction level, according to the perception of Hitachi Chemical employees in Montemorelos, Nuevo León, México? This study’s design is both explanatory and cross-sectional. The sample size was composed of 143 Hitachi Chemical employees of Montemorelos, Nuevo León, México. For the data collection, two instruments were used: the first instrument was used to measure the quality of organizational climate and the second was focused on measuring the workplace satisfaction level. As a result, the level of organizational climate quality is in fact a predictor of workplace satisfaction of Hitachi Chemical employees. After the regression analysis, it was found that the variable, level of organizational climate, explained a $71.4 \%$ variance in the dependent variable, work satisfaction. It was determined that organizational climate is a strong predictor of work satisfaction perceived by employees of Hitachi Chemicals, Montemorelos, Nuevo León, México. It can be established that the greater the levels of organizational climate experienced by the employees, the greater the level of work satisfaction will be.
\end{abstract}

Keywords: organizational climate, work satisfaction, employees' satisfaction, organizational environment, performance, job management

\section{Introduction}

Corporations, no matter their size, need to know the level of work satisfaction and how it is influenced by organizational climate. Organizational climate, according to Sandoval Caraveo (2004), is a susceptible characteristic that is measured by an organization, which influences the behavior of individuals. Organizational climate plays a very important role as a tool to improve the work satisfaction of employees and their performance in organizations despite their size. Studies made on this subject and that are presented in this paper show that there are significant relations between organizational climate and work satisfaction. The

Omar A. Flores Laguna, Director of the Research Department for Business, Facultad de Ciencias Empresariales y Juridicas, University of Montemorelos. Email: oflores@um.edu.mx.

Sandy M. Velázquez Hernández, Master Student, Facultad de Ciencias Empresariales y Juridicas, University of Montemorelos. Karla S. Basurto Gutiérrez, Graduated Professor, Facultad de Ciencias Empresariales y Juridicas, University of Montemorelos. Karla L. Haro-Zea, Fulltime Research Professor, Facultad de Contaduría Pública, Meritorious Autonomous University of Puebla. 
implementation of this process can contribute to the achievement of a superior performance in comparison to the competition and can be a starting point in having a successful management and work performance. For that reason, it is considered important to carry out a study on the subject for one of the most important corporations in the town of Montemorelos in the state of Nuevo León, México.

Hitachi Chemical México was founded in 2008, it is a corporation that makes auto parts and accessories (disc pads for cars) and has their headquarters in Tokyo, Japan.

The study of organizational climate as a predictor of work satisfaction can generate a positive impact and can be a factor of efficient influence not only in work performance of Hitachi Chemicals, but for any other corporation. The purpose of this study was to know the quality level of organizational climate, knowing the work satisfaction level and to identify the level in which organizational climate is a predictor of work satisfaction of Hitachi Chemical employees in Montemorelos, Nuevo León, México.

\section{Contribution and Benefits of the Study}

This study benefits the managers since they need to consider employees as the most valuable asset and also to invest in them in accordance with their role within the corporation, providing them with continuous opportunities to further develop their skills. This study justifies on the existing impact of organizational climate perceived over work satisfaction, which is manifested by the employee's performance in his/her work.

This study's agenda is organized in the following manner: in literary revision, past studies of organizational climate as a predictor of work satisfaction are addressed. In the following section, the method, target population, the utilized instrument, and the operationalization of variables both utilizing the simple regression method and the least squares method, and subsequently both descriptive and inferential results are presented. In the conclusions, we present an abstract of the most important findings, and limitations of studies and recommendations for future studies are also addressed.

\section{Theoretical Framework}

Álvarez (2001), Segredo Pérez and Reyes Miranda (2004), and Méndez (2006) defined organizational climate as an ensemble of predominant characteristics in the internal environment in which the organization operates, which exercises a strong influence on conducts, beliefs, values, and perceptions of the people, determining their behavior and levels of satisfaction.

According to Toro (1992), the organizational climate is the assessment or perception that people develop from their realities within their workplace. Said perception is the product of a formation process of concepts that are originated in the interrelation of events and qualities of the organization. The perceptions can refer to structural processes like supervisory style, organizational policies, practices, and procedures and work environment, among others. It is a multidimensional concept, because of this, it has been confirmed that organizational climate is incorporated of a group of properties or characteristics of the internal work environment, perceived directly or indirectly by the employees of an organization, influencing the employees' behavior according to Martínez (2001).

Rodríguez, Retamal, Lizana, and Cornejo (2011) noted that studying organizational climate promotes the continuous improvement of the work environment in all of the corporations, due to it being one of the determinant elements in the organizational processes and the motivational tendencies of people. 
The importance of analyzing this variable is mainly founded upon the generation of results that can contribute to the implementation of programs for full development of labor conditions, quality of life, and the participation level of the collaborators towards success within the private and public sector institutions.

Price and Muller (1986) identified work satisfaction with the level in which the individuals enjoy their work. Blum and Naylor (1990) stated that work satisfaction is the result of different answers and attitudes generated towards their working conditions, such as salaries, supervision, tenacity, growth opportunities, recognition, performance reviews, social relationships, conflict resolutions, fairness and other similar concepts. Davis and Newstrom (2007) defined work satisfaction as an ensemble of both positive and negative feelings in which the employees perceive their work.

Work satisfaction is important because it is widely linked to productivity, performance, and worker absenteeism. The ideal thing would be having both satisfied and productive workers. But some attempts in boosting productivity can lower work satisfaction. In the same way, high level of satisfaction is not an assurance of high productivity according to Muchinsky (2002).

Martín (2008) claimed that the subject of work satisfaction is of great interest because it indicates the ability of an organization to satisfy the needs of workers and there are proofs showing that employees with low levels of satisfaction tend to quit their jobs more often while employees with high levels of satisfaction have better health and live longer.

Torres (2006) added that work satisfaction improves the global productivity of an organization and cuts down on occupational burnout. Thus, the study of organizational climate needs to be a necessary action to determine factors that need to be treated for the purpose of improving the organizational climate in the organization, institution, or corporation.

Juárez Adauta (2012) conducted a study to determine the relationship between organizational climate and work satisfaction in the Hospital General Regional 72 del Instituto Mexicano del Seguro Social en Tlalnepantla de Baz, state of México. It was an observational, cross-sectional, descriptive, and analytical study; the target population was constituted by a total of 230 people: $58.3 \%$ women and $41.7 \%$ men. A high positive correlation was found between work satisfaction and organizational climate $(r=0.83, p=0.001)$.

Peña Cárdenas, Díaz Díaz, and Carrillo Puente (2015) conducted a study with the purpose to know the existing relationship between organizational climate and work satisfaction of office and operational workers in a small family-owned business of the metal-working industry in Monclova, Coahuila. The structured questionnaire was applied to 20 workers. The results were pilot-tested using Cronbach's Alpha. The outcome was 0.851 and 0.890 , for organizational climate and work satisfaction respectively. It was concluded that there is a significant relation between both constructs.

Chiang Vega, Salazar Botello, and Núñez Partido (2007) conducted a study with the purpose of knowing the relationship between organizational climate and work satisfaction on workers of the state's health sector. The sample of this work is composed of 327 workers, members of 14 services of Group A hospital. To diagnose the work environment, a questionnaire based on Likert scale was applied. The reliability analysis of the questionnaires leads to coefficient Cronbach's Alpha for the scales of both organizational climate and work satisfaction of 0.969 and 0.925 , respectively. The structure of scales is studied through an exploratory factorial analysis. Regarding the result of organizational climate concerning work satisfaction, it was found that there are existing dimensions of organizational climate that have statistically significant relations with work satisfaction variables. 
Chiang Vega, Gómez Fuentealba, and Salazar Botello (2014) conducted a study of organizational climate, work satisfaction, and its results on work teams consisting of professors and/or researchers working in the college faculty. The sample was composed of professors and research members of 42 work groups (departments), of which 18 from Spanish universities and 24 from Chilean universities. The study shows that there are significant statistic relations existing between the three analyzed variables. In the Spanish sample, productivity is related with work pressure, satisfaction, and academic development.

Schratz (1993) found through a meta-analysis function existing dimensions between organizational climate and work satisfaction which historically have been related amongst each other. Organizational climate dimensions that have related the most with work satisfaction are management support, incentives, responsibility (individual autonomy), interpersonal relations (friendliness), and employee skills. Work satisfaction dimensions that have been related the most to organizational climate are satisfaction with salary, management, work peers, and promotion.

\section{Methodology}

The study was quantitative, descriptive, explanatory, and cross-sectional. The target group for the current study consists of 200 Hitachi Chemical México employees; the sample is composed of 143 employees. The sample has the following characteristics: (1) gender: female (29.4\%) and male (70.6\%); (2) age: 20-30 yrs (60.8\%), 31-40 yrs (30.1\%), 41-50 yrs (8.4\%), and 51-60 yrs (7.0\%); (3) time working at the company: 0-5 yrs (69.9\%), 6-10 yrs (9.1\%), 11-15 yrs (11.9\%), and 16 or more yrs (9.1\%); (4) academic grade: primary school (1.4\%), secondary school (42\%), high school (28\%), bachelor's degree (14\%), and postgraduate degree (14.7\%).

For the collection of data, a questionnaire made by Campos Madrigal and Meza Escobar (2013) was used. This contains a scale to measure organizational climate, and it consists of 17 criterions valued by a 7-point Likert scale, ranging from 1 = Awful, 2 = Very bad, 3 = Bad, $4=$ Normal, $5=$ Good, $6=$ Very good and 7 = Excellent. The level of reliability measured by Cronbach's Alpha was 0.948. For work satisfaction, an adaptation of the instruments part I by Delgado González (2011) was used, which consists of 15 items valued on a 7-point Likert scale. The level of reliability measured by the Cronbach’s Alpha was 0.926 .

\section{Results}

\section{Descriptive Statistics}

In this section, the results of the arithmetic means of each construct with indicators and the significance of the hypothesis trials are presented.

Through the analysis of data from 143 employees, we get an arithmetic mean of 4.29 for the organizational climate level quality perceived by Hitachi Chemical in Montemorelos, Nuevo León, México employees. According to the grading used on the Likert scale, the employees' perception of organizational climate was considered regular.

In Table 1, arithmetic mean of the declarations is shown and it was found that the best-evaluated aspects of the organizational climate quality perceived by the employees level were: (1) "the quality of interpersonal relationships amongst fellow coworkers" $(M=5.10, S D=1.34)$; (2) "quality level of work tools and/or work equipment" $(\mathrm{M}=4.66, \mathrm{SD}=1.36)$; (3) "control system or facility security” ( $\mathrm{M}=4.65, \mathrm{SD}=1.26)$; (4) "employee commitment level with the organization's mission statement” ( $\mathrm{M}=4.61, \mathrm{SD}=1.45)$; and (5) "quality of interpersonal relationships between superior and subordinates" ( $M=4.58, \mathrm{SD}=1.49)$. 
On the basis of the arithmetic mean, it was established that the aspects with the lowest grades concerning organizational climate quality perceived by the employees were the following: (1) "employees' motivation level for performing tasks" $(\mathrm{M}=4.08, \mathrm{SD}=1.59)$; (2) "staff selecting procedure" $(\mathrm{M}=4.05, \mathrm{SD}=1.55)$; (3) "organization's support towards achieving personal objectives" ( $\mathrm{M}=3.88$, SD = 1.61); (4) "promotion opportunities" ( $\mathrm{M}=3.76, \mathrm{SD}=1.61)$; and (5) "pay system level (salaries, benefits, health insurance, pensions, etc.)" $(\mathrm{M}=3.71, \mathrm{SD}=1.66)$.

Based on the data analysis of 143 employees, an arithmetic mean of 4.23 was obtained for the work satisfaction level perceived by employees of Hitachi Chemical in Montemorelos, Nuevo León, México. According to the points on the Likert scale used, the perception of the employees' work satisfaction variable was evaluated regular.

The arithmetic means of the statements are shown in Table 2. The aspects with the highest grades for the work satisfaction perceived by the employees were: (1) "relationships with co-workers" ( $M=5.33, \mathrm{SD}=1.40$ ); (2) "relation amongst department workers" $(\mathrm{M}=5.24, \mathrm{SD}=1.29)$; (3) "freedom to perform their work" $(\mathrm{M}=4.99, \mathrm{SD}=1.63)$; (4) "with their work" $(\mathrm{M}=4.94, \mathrm{SD}=1.49)$; and (5) "relationship with their direct superior” ( $\mathrm{M}=4.75, \mathrm{SD}=1.68)$.

Based on the arithmetic mean, it was determined that the lowest evaluated aspects on the work satisfaction perceived by the employees were the following: (1) "professional advancement opportunities" ( $\mathrm{M}=3.94$, $\mathrm{SD}=1.71$ ); (2) "retirement plan” ( $\mathrm{M}=3.83, \mathrm{SD}=1.54)$; (3) "additional yearly benefits” ( $\mathrm{M}=3.68, \mathrm{SD}=1.63$ ); (4) "organization's recreational activities" $(\mathrm{M}=3.66, \mathrm{SD}=1.86)$; and (5) "salary received" $(\mathrm{M}=3.32$, $\mathrm{SD}=1.62)$.

Table 1

Arithmetic Means of Organizational Climate

\begin{tabular}{llll}
\hline Statements & $N$ & M & SD \\
How do you perceive the following in Hitachi Chemical? & 143 & 4.58 & 1.49 \\
\hline Quality of interpersonal relationships between superior and subordinates & 5.10 & 1.34 \\
The quality of interpersonal relationships amongst fellow coworkers & 143 & 4.10 & 1.70 \\
Work acknowledgement by superior & 143 & 4.08 & 1.59 \\
Motivation level for performing tasks & 143 & 4.61 & 1.45 \\
Commitment level with the organization's mission statement & 143 & 4.25 & 1.61 \\
Communication within the organization & 143 & 4.05 & 1.63 \\
Staff selecting procedure & 143 & 1.47 \\
Head of the department leadership quality & 143 & 1.36 \\
Quality of physical environment of the work areas & 143 & 4.34 & 1.26 \\
Quality level of work tools and/or work equipment & 143 & 4.66 & 1.64 \\
Control system or facility security & 143 & 4.65 & 1.61 \\
Training program & 143 & 4.16 & 1.66 \\
Organization's support towards achieving personal objectives & 143 & 3.88 & 1.61 \\
Pay system level (salaries, benefits, health insurance, pensions, etc.) & 143 & 3.71 & 1.51 \\
Promotion opportunities & 143 & 3.76 & 1.44 \\
Observance to office rules & 143 & 4.22 & 1.13 \\
Organization's ethic stand & 143 & 4.45 & 4.29 \\
Total & 143 & & \\
\hline
\end{tabular}


Table 2

Arithmetic Means of Work Satisfaction

\begin{tabular}{llll}
\hline Statements & $N$ & $\mathrm{M}$ & $\mathrm{SD}$ \\
How satisfied do you feel with the following? & 143 & 4.25 & 1.61 \\
\hline Your workload & 143 & 3.32 & 1.62 \\
Your salary & 143 & 3.68 & 1.63 \\
Your work benefits & 143 & 4.64 & 1.65 \\
Treatment you receive from your direct superior & 143 & 5.33 & 1.40 \\
Your relationship with your co-workers & 143 & 5.24 & 1.29 \\
Your relationship with your peers & 143 & 3.94 & 1.71 \\
Professional advancement opportunities & 143 & 4.50 & 1.50 \\
Attention to personal needs by your direct boss & 143 & 3.83 & 1.54 \\
Retirement plan & 143 & 4.05 & 1.79 \\
Professional training received & 143 & 4.01 & 1.52 \\
Facilities to acquire technological resources & 143 & 3.66 & 1.86 \\
Recreational activities organized by the company & 143 & 4.75 & 1.68 \\
Your relationship with your direct superior & 143 & 4.94 & 1.49 \\
Your work & 143 & 4.99 & 1.63 \\
Freedom to perform your work & 143 & 4.23 & 1.05 \\
Total & & \\
\hline
\end{tabular}

\section{Sample Normality Tests}

A Kolmogorov-Smirnov test to see the constructs' normality of organizational climate and work satisfaction was made and it was found that the value of $p$ is greater than 0.5 which is the reason why it is assumed that the constructs present a normal distribution. Furthermore, both constructs' normality in relation to demographic variables (age, gender, seniority, and academic grade) was analyzed. When the constructs with the demographic variables were analyzed, the following criterions were used: (1) if in the groups $n$ is greater or equal to 50, the Kolmogorov-Smirnov test was used; and (2) if in the groups $n$ is lower or equal to 50, the Shapiro-Wilks test was used.

While performing the normality tests, it was found that in the groups, the probabilities were greater than 0.05. Thus, the conclusion is that the constructs in relation to the demographic variables are normal, which means that parametric tests can be implemented in this research.

\section{Null Hypothesis Tests}

In this section, the statistical tests of the four formulated null hypotheses for this study are presented.

$\mathrm{H}_{0}$ : The quality level of organizational climate is not a predictor of the work satisfaction level, according to the perception of employees of Hitachi Chemical in Montemorelos, Nuevo León, México.

For the analysis of this hypothesis, simple lineal regression was applied; quality of organizational climate was considered as an independent variable and work satisfaction level was considered as a dependent variable.

While applying the regression analysis, it was found that the organizational climate level variable explained $71.4 \%$ of the variance of the dependent variable work satisfaction. The value of $R^{2}$ is equal to 0.714 . The $F$-statistic is equal to 355.62 and it contrasts the null hypothesis that the value of $R$ is 0 . Because the value of $p$ is equal to 0.000 this indicates that there is an existent significant positive lineal influence between organizational climate and work satisfaction in the employees of Hitachi Chemical, Montemorelos, Nuevo León. 
The values of the non-standardized $B k$ coefficient, obtained by utilizing the statistical regression technique were: $B_{0}$ equal to 0.861 and $B_{1}$ equal to 0.785 . With said values, the following regression equation was constructed utilizing the method of least squares: work satisfaction $=0.861+0.785$ (organizational climate).

Organizational climate resulted to be a predictor of work satisfaction (standardized beta equal to 0.846 and $p$ equal to 0.000 ).

\section{Complementary Hypothesis}

Hereunder, the complimentary hypotheses for this study are presented:

$\mathrm{H}_{01}$ : There is not a significant existence of the level of organizational climate perceived by Hitachi Chemical employees, according to their age.

$\mathrm{H}_{02}$ : There is no existing difference between the level of organizational climate perceived by the Hitachi Chemical employees, according to their gender, seniority or academic grade.

$\mathrm{H}_{03}$ : There is not existent significant difference in the work satisfaction level by the employees of Hitachi Chemical, according to their time at the company.

$\mathrm{H}_{04}$ : There is no existing significant difference in the level of work satisfaction perceived by the employees of Hitachi Chemical, according to their gender, seniority and academic grade.

Testing of Null Hypothesis 1. Factorial analysis of variance was made to test $\mathrm{H}_{01}$. The dependent variable organizational climate was considered. The independent variable considered for this hypothesis was age.

The result of the factorial analysis of variance was $F=4.908$ and $p=0.009$. Because the statistical significance was less than 0.05 , the null hypothesis was rejected and it was concluded that the target population differs significantly if considered by the age variable in the level of organizational climate perceived by employees of Hitachi Chemical Nuevo León, México.

Given that the null hypothesis was rejected, the equality of variances was evaluated using Levene's test. Levene's test allows the assessment of equality of variances for a variable calculated for two or more groups. The critical value was 0.455 which is greater than 0.05 ; it was decided to retain the hypothesis of equal variances. It was also considered that the target population's variances were equal.

To determine which categories differ, many post hoc or posteriori comparison tests were used. Because it was assumed that there were many population variances, Scheffe's test was used. It was found that the age group that had significant differed was the 31-40 yrs one, with an arithmetic mean of 3.96 and the age group of 41-50 yrs with an arithmetic mean of 5.04 .

Testing of Null Hypothesis 2. To test $\mathrm{H}_{02}$, a factorial analysis was applied. Organizational climate was considered as a dependent variable. The independent variables considered in this hypothesis were gender, seniority, and academic grade.

The statistical test applied in this hypothesis was the factor variance analysis, which produced an $F$-value of 1.107 and a $p$ significance level of 0.347 . Because the significance level was greater than 0.05 , it was decided to retain the null hypothesis and it was concluded that the population variances gender, seniority, and academic grade do not differ significantly in the level or organizational climate perceived by the employees of Hitachi Chemical Nuevo León, México.

Testing of Null Hypothesis 3. To test $\mathrm{H}_{03}$, a factor variance analysis was applied. Work satisfaction was considered as a dependent variable. The considered independent variable in this hypothesis was the time at the company. 
The statistical test applied for this hypothesis was the factor variance, which gave as result an $F$-value of 5.546 and a significance $p$ level of 0.009 . Because the signification level was less than 0.05 , it was decided to reject this null hypothesis and it was concluded that there is a significant difference in work satisfaction perceived by the employees of Hitachi Chemical Nuevo León, México in the population’s time variable.

Given that the null hypothesis was rejected, using Levene's test, the equality of variances was evaluated. Levene's test allows for the contrast of the hypothesis that population variances are equal. Because the critical value ( $p$ is equal to 0.114 ) was greater than 0.05 , it was decided to retain the hypothesis of variance equality. It was also considered that the population variances are equal.

To determine which categories differ, many post hoc or posteriori comparison tests were used. Because it was assumed that the population variances were equal, Scheffe's test was used. It was found that time groups that differed significantly the most were the following: (1) 20-30 yrs with an arithmetic mean of 4.22 and the 41-50 yrs with an arithmetic mean of 5.09; and (2) 31-40 yrs with an arithmetic mean of 3.48.

Testing of Null Hypothesis 4. To test $\mathrm{H}_{04}$, factorial analysis of variance was used. The level of work satisfaction was used as a dependent variable. The independent variables that were considered for this hypothesis were: gender, seniority, and academic grade.

The factorial analysis of variance gave as a result an F-value of 1.093 and significance level of $p$ of 0.425 . Given that the critical value of significance was greater than 0.05 , it was decided to retain the null hypothesis and it was concluded that the population's variables, gender, seniority and academic grade, differ significantly in the level of work satisfaction perceived by the employees of Hitachi Chemical, Nuevo León, México.

\section{Conclusion}

The purpose of this study was to determine if the quality level of organizational climate is a predictor of work satisfaction of the employees at Hitachi Chemical, Montemorelos.

With the support of statistical techniques for the considered sample, it was concluded that the level of organizational climate perceived by the employees has a level of positive lineal influence and a strong influence in the level of work satisfaction in employees of Hitachi Chemical, Montemorelos.

It can be affirmed that, the greater the level of organizational climate, the greater the level of work satisfaction perceived by the employees of Hitachi Chemical, Montemorelos will be.

\section{Complimentary Hypothesis}

By analyzing the obtained results for the complimentary hypothesis, it was determined that there was a significant effect in age by the quality level of organizational climate and work satisfaction, which means that the level of organizational climate and work satisfaction is affected by the age of the employees.

The gender, seniority, and academic grade variables did not have a significant effect over the level of organizational climate and work satisfaction, which means that the perceptions of organizational climate and work satisfaction are not affected by gender and academic level.

This study benefits managers due to them having to consider employees as the most valuable resource and invest in them for their importance within the organization, continuously providing them with opportunities to improve their skills. It is recommended: establishing programs and practices that promote high levels of motivation according to ages of the employees, so that they can improve their performance in their jobs; increasing the levels of acknowledgement of superiors towards their subordinates when they do a good job. 
Work acknowledgement is vital to the formation of a healthy work environment; creating promotion opportunities so that the employees are motivated to progress professionally and maintain a positive work environment; creating salary policies about the basic parameters of efficiency and measurable results. This generates a goal-oriented environment and encourages effort; Offering employees better benefits to favor a higher work satisfaction; and continuing to reinforce the aspects that have been best perceived by the employees.

\section{References}

Álvarez, S. (2001). La cultura y el clima organizacional como factores relevantes en la eficacia del Instituto de Oftalmología (tesis para obtención de grado). Universidad Nacional Mayor de San Marcos, Lima, Perú.

Blum, M., \& Naylor, J. (1990). Psicología industrial: sus fundamentos teóricos y sociales (2nd ed.). México: Trillas.

Campos Madrigal, C. I., \& Meza Escobar, M. R. (2013). Modelo de asociación entre factores de satisfacción y desempeño laboral en docentes universitarios (Tesis doctoral). Montemorelos, México: Universidad de Montemorelos.

Chiang Vega, M. M., Gómez Fuentealba, N. M., \& Salazar Botello, C. M. (2014). Satisfacción laboral y estilos de liderazgo en instituciones públicas y privadas de educación en Chile. Cuadernos de Administración, 30(52), 65-74.

Chiang Vega, M. M., Salazar Botello, C. M., \& Núñez Partido, A. (2007). Clima organizacional y satisfacción laboral en un establecimiento de salud estatal: hospital TIPO 1. Theoría: ciencia, arte y humanidades, 16(2), 61-76.

Davis, K., \& Newstrom, W. (2007). El comportamiento humano en el trabajo. Comportamiento organizacional. México: McGraw-Hill.

Delgado González, M. (2011). Satisfacción laboral de docentes y directivos de escuelas adventistas de nivel básico y medio superior de México (Tesis de maestría). Universidad de Montemorelos. Montemorelos, México.

Juárez Adauta, S. (2012). Clima organizacional y satisfacción laboral. Revista Medica del IMSS, 50(3), 307-314.

Martín, P. (2008). Estudio comparativo de la satisfacción laboral en el personal de administración. Revista de Psicología del trabajo y de las organizaciones, 24(1), 25-40.

Martínez, B. (2001). Análisis del clima laboral: una herramienta de gestión imprescindible. Análisis del clima laboral. Retrieved from http://www.kpmg.com.uy/circulares/Recursos\%20Humanos/12-Analisis\%20de\%20clima\%20laboral.htm

Méndez, C. (2006). Clima organizacional en Colombia. El IMCOC: un método de análisis para su intervención. Bogotá, Colombia: Centro Editorial Universidad del Rosario.

Muchinsky, P. (2002). Psicología aplicada al trabajo. México: Cengage Learning.

Peña Cárdenas, M. C., Díaz Díaz, M. G., \& Carrillo Puente, A. (2015). Relación del clima organizacional y la satisfacción laboral en una pequeña empresa familiar. Revista Internacional Administración y Finanzas (RIAF), 8(1), 37-50.

Price, J. L., \& Muller, C. W. (1986). Absenteeism and turnover among hospital employees. Greewich, UK: JAI Press.

Rodríguez, A. A., Retamal, M. P., Lizana, J. N., \& Cornejo, F. A. (2011). Clima y satisfacción laboral como predictores del desempeño: en una organización estatal chilena. Salud y Sociedad, 2(2), 219-234.

Sandoval Caraveo, M. C. (2004). Concepto y dimensiones del clima organizacional. Hitos de Ciencias Económico Administrativo, 10(27), 33-40.

Schratz, M. (1993). Recommendations for the measurement of organizational climate. Toronto, Ontario, Canadá: APA.

Segredo Pérez, A. M., \& Reyes Miranda, D. (2004). Clima organizacional en salud pública. Consideraciones generales. Revista Correo Científico Médico de Holguín, 8(3), 3.

Toro, F. (1992). Clima organizacional y expectativas en la perspectiva del cambio organizacional. Revista Interamericana de Psicologia Ocupacional, 11(2), 163-173.

Torres, N. D. (2006). Diagnóstico sobre las preferencias de clima organizacional de los bibliotecarios universitarios: el caso de las universidades de São Paulo y Antioquia. RevistaInteramericana de Bibliotecología, 29(2), 99-117. 